\title{
THE IMPACT OF BALINESE WOMEN'S POWER IN THE HOUSEHOLD ON CHILD WELFARE
}

\author{
Putu Ayu Pramitha Purwanti ${ }^{1}$ and Ni Luh Karmini ${ }^{2}$ \\ ${ }^{1}$ Faculty of Economics and Business, Udayana University, Denpasar, Indonesia \\ ${ }^{2}$ Faculty of Economics and Business, Udayana University, Denpasar, Indonesia
}

DOI: 10.46609/IJSSER.2020.v05i11.007 URL: https://doi.org/10.46609/IJSSER.2020.v05i11.007

\begin{abstract}
The study aims to examine the influence of Balinese women's power in the household on child welfare. The data used are household-level that is households with women born in Bali, having a spouse who is still alive, and having school-age children (aged 7-18 years old). Analysis using the ordinary least square (OLS) model. Women's power is measured relatively in ratio. The first measure is the ratio of women's education compared to their spouse's education. The second measure is the ratio of wages received by women compared to the wages of their spouse. Results show that the power of Balinese women in the household has a significant influence on improving children's welfare. The higher the education of women compared to their partners, which indicates the greater the power of women in the household, the higher the level of child welfare. The higher the level of wages for Balinese women compared to their partners, the higher the level of child welfare. This indicates that women's empowerment through their role in household decision making can be done by opening access to education and access to work in the labor market with a fair wage system.
\end{abstract}

Keywords: Balinese women, Child welfare, Decision making, Household, Women's power

\section{Introduction}

The parental power in the household that is comparatively greater than the power of children causes children to tend to be more dependent on their parents. The level of child welfare is inseparable from the intervention of the mother because by using her abilities, the mother allocates various resources owned by the household. It depends on the amount of power a mother has in the household to carry out her preferences [2]. Individual power in the household affects the level of child welfare. Individual power can be measured by many indicators, two of them are education and income (wages) [7]. Education and income can be used as an absolute and relative 


\section{International Journal of Social Science and Economic Research}

ISSN: $2455-8834$

Volume:05, Issue:11 "November 2020"

measure of power. The measurement of power relatively provides a more complex picture, not only the individual concerned but also the picture of the comparison used [1].

The power held by men (fathers) and women (mothers) in the household can have different effects on the welfare of children. Lundberg et.al. [5] examined the impact of changing the distribution system of resources in a household on its expenditure. The Child Benefit Program (public assistance program for families with children) in the United Kingdom was initially given to men and then the system was replaced by providing assistance directly to women. This has an impact on the occurrence of shifts in family expenses, from men's clothing to women's and children's clothing. The shift in expenditure shows that there are differences in preferences between men and women when there is a change in the distribution of resources within the household. These changes lead to increased child welfare when resources are managed by women. Dufflo [3] also found a similar case where the expansion of the pension program in South Africa had a positive effect on the anthropometric status of girls when the pension recipient was female and the program had no impact when the recipient of the program was male. Identification of the consequences of women's power in the household is a very important study because it has implications for the importance of planning for women's empowerment in efforts to improve children's welfare.

This study aims to examine the influence of Balinese women's power in the household on child welfare. Welfare can be measured both materially and non-materially. The level and pattern of household expenditure can directly illustrate the level of household welfare. The greater the household expenditure, the better the level of household welfare because more and more needs can be met. One form of household expenditure is children's clothing expenditure. This form of expenditure illustrates the level of fulfillment of the need for children's clothing. The higher expenditure on clothing indicates the level of child welfare is increasing. The novelty of this study is to consider the role of culture in child welfare. The kinship system as a form of culture prevailing in Balinese society is dominated by patrilineal culture, which is a culture that prefers male lineage [4]. In general, the patrilineal kinship system assesses that boys are higher than girls. The patrilineal system indicates the importance of male descendants (sentanapurusa) in the family who will carry on the rights and obligations of parents and ancestors in the activities of social, customary, cultural and religious life [6]. In this study, it will be tested whether boys and girls have different effects on the expenditure of their clothing. Testing the influence of women's power in the household on children's welfare by considering the role of culture provides an alternative reference for planning policies that aim to improve children's welfare. One of them is the demand for opening access that can increase the role of women in household decision making. 
International Journal of Social Science and Economic Research

ISSN: 2455-8834

Volume:05, Issue:11 "November 2020"

\section{Method and Procedure}

This study uses primary data from households in the province of Bali. Data at the household level. The sample frame is households with Balinese women who are married, working, have a life partner, and have school-aged children (7-18 years). Primary data analysis is supported by secondary data in the form of literature studies and publication documents published by related agencies. The collection of primary data was carried out using a questionnaire that was supported by in-depth interviews with policymakers related to women's empowerment. The sample was chosen using the proportional random sampling method where the order of collection is stratified at the district/city level. The number of samples is determined based on quota because the population size is not known with certainty. Quota sampling is a technique for determining samples from populations that have certain characteristics to the desired amount (quota). The minimum number of samples is based on 10 times the number of independent variables. Samples are taken by giving certain quorums to groups. The total sample will be distributed proportionally in each district/city in the Province of Bali. The number of samples was 388 households.

The empirical model of the consequences of Balinese women's power is carried out with the ordinary least square model considering that the dependent variable used is a ratio variable [9]. The OLS model used is:

$C W_{i}=\alpha_{0}+\theta_{i} \beta_{i}+\boldsymbol{R} \boldsymbol{T}_{i} \gamma_{i}+\varepsilon_{i}$

$\mathrm{CWi}=$ expenditure of children's clothing.

$\theta=$ women's power in the household (education ratio, wage ratio)

RT = household characteristics (age, household assets, number of household members, location of residence).

The dependent variable to test the consequences of women's power on child welfare is the level of child welfare measured by the amount of household expenditure used to purchase children's clothing in the past year $(\log )$. The independent variables are household characteristics that affect the level of child welfare. The first variable is women's power in the household as measured by the ratio of the last education completed by women to their spouse's education and the ratio of wages that women receive to their spouse's wages. Other variables are the age of the woman and the age of her partner (years), the number of household members (person), the age of the child (years), the sex of the child (boy/girl), household assets, and location of residence (urban/rural). The last three variables are binary variables. For assets, the question given is "does it have 


\section{International Journal of Social Science and Economic Research}

ISSN: $2455-8834$

Volume:05, Issue:11 "November 2020"

certain assets (savings, jewelry, non-agricultural land)?". If you have assets $=1$; has no assets = 0 .

\section{Result}

The general description of the sample can be seen in Table 1. The childclothes variable is a dependent variable that describes the amount of household expenditure used to purchase children's clothing. This variable measures the level of child welfare. The greater the value of this variable shows the more children's clothing needs fulfilling so that the child is more prosperous. Women's power in the household is measured based on the ratio value which shows the quality of human capital, that is, the last education completed. On average, women's education is still higher than their spouse's education.

\section{TABLE 1}

\section{Descriptive Statistics}

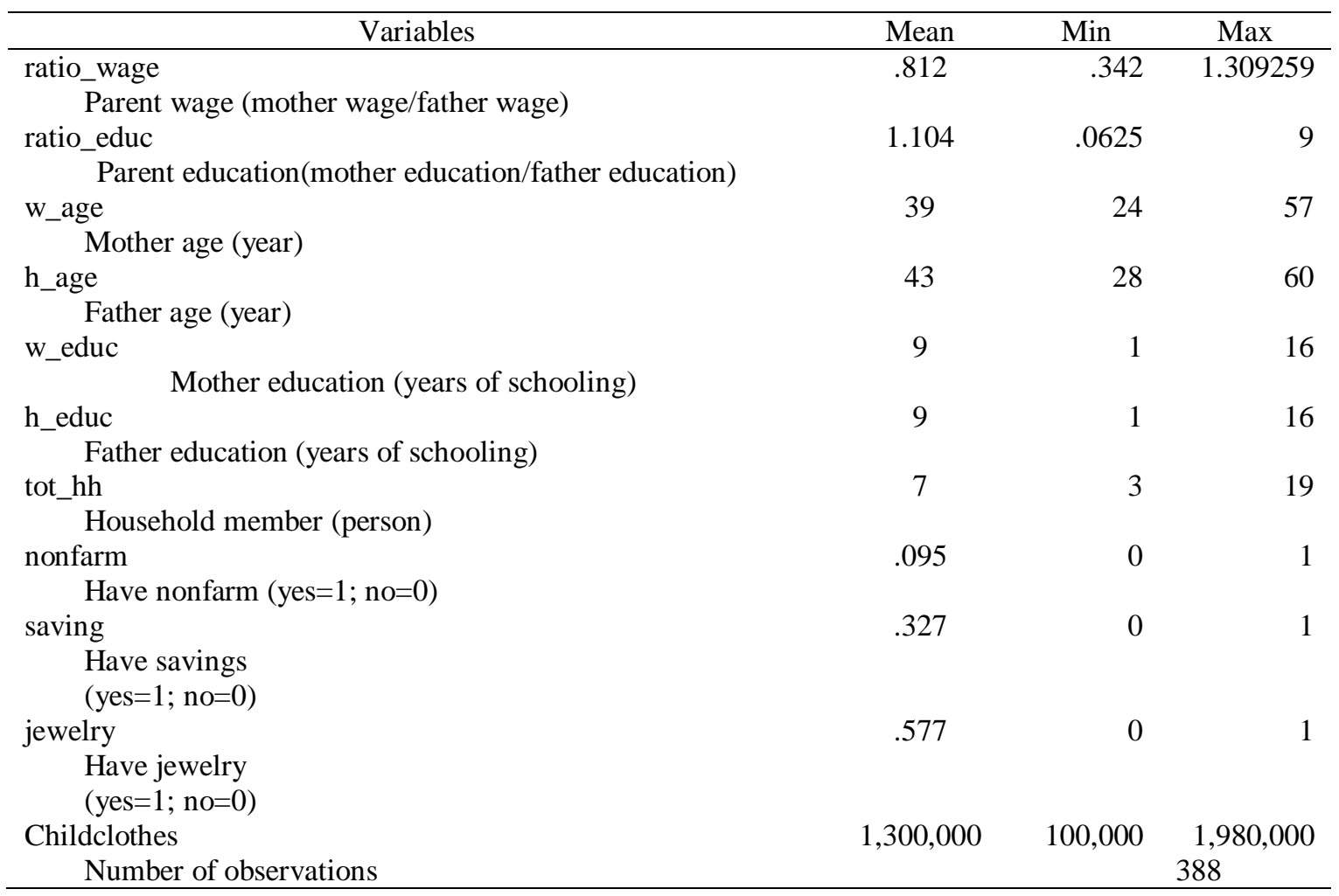

Based on wage rates, women's wages are still lower compared to their partners (wage ratio mean is under one). This indirectly indicates, first, in the patrilineal kinship system, men are the breadwinners of the household who are responsible for the survival of the household. This 


\section{International Journal of Social Science and Economic Research}

ISSN: $2455-8834$

Volume:05, Issue:11 "November 2020"

condition requires them to work and give more resources to the household [8] compared to women, although it does not rule out a woman being able to become the head of the household. The majority of respondents, men as heads of households. Second, there is a possibility of gender differences in the wage system which tends to marginalize women and give a lower value compared to men. This is still a lot happening especially in developing countries.

The age range of women is 24 years to 57 years with an average of 39 years old. Slightly different from the condition of men as their partners, on average they are 43 years old. The average age of women is younger than their spouses. The average number of household members is seven. This shows a fairly large household. The number of household members illustrates their competition in obtaining resources owned by the household. The greater the number of household members, the higher the level of competition so that the level of individual utility in the household for resource consumption will be lower. On the other hand, if the majority of household members are of productive age, the addition of household members will actually increase the total household resources. At the productive age, the level of individual productivity is higher so that the income earned is also higher. An increase in income will add to the total household resource which allows households to increase their expenditure. Assets are an indicator of the level of household welfare. Households with assets have a higher level of "security" compared to households without assets. This is especially felt when households experience shocks that interfere with the sustainability of household consumption. Assets become reserves that can be used by households when households experience a "threat" of consumption. The higher the value of the assets owned, the more prosperous the household is, and the smaller the risk faced by households when experiencing economic shocks. More than half of the households have assets in the form of jewelry, while only a few households have nonfarm or savings assets. The location of residence determines household characteristics. Such as rural and urban locations. Different urban and rural characteristics that affect the behavior of households living in each of these regions. Judging from the sample used, the majority of sample households reside in urban areas.

Women's power is measured by the ratio of education (columns 1 - 4) and the wage ratio (columns 5 -8). Table 2 shows that women's power significantly influences children's welfare. Column one shows that the power of women (mothers) has a significant effect on children's welfare at a five percent confidence level. When other determinants of child welfare, namely mother's wages and father's wages are included, the role of maternal power decreases. Mother's wages and father's wages have a greater role than maternal power (column 2). Even so, maternal power still has a significant role in improving children's well-being. The higher the education of women compared to the education of their spouses, the higher the level of child welfare. This shows that education for women is very important. Open access to women's education will 


\section{International Journal of Social Science and Economic Research}

ISSN: $2455-8834$

Volume:05, Issue:11 "November 2020"

increase the welfare of children. Associated with a patrilineal culture which values boys more than girls, does not occur in the respondent's household. The sex of the child does not significantly affect the welfare of the child so there is no difference in welfare between boys and girls. The number of household members has a positive effect on children's welfare. Increasing the number of household members will increase the amount of household expenditure to meet the needs of children's clothing. This proves that there is no competition in the use of household resources for children's clothing expenditure. This also indicates that the majority of household members are in the productive age so that they are able to contribute to household resources that can increase children's clothing expenditure.

Household assets play an important role in improving children's welfare. Children who live in households with assets such as non-agricultural land or jewelry have a higher level of welfare compared to households that do not have these assets. The location of residence shows the differences in the welfare of children who live in urban areas with children who live in rural areas. Households living in rural areas have higher child clothing expenditures. It means they have a higher level of welfare compared to children in urban areas.

TABLE 2

The Consequences of Bali Women's Power on Child Welfare.

\begin{tabular}{|c|c|c|c|c|c|c|c|c|}
\hline VARIABLES & $(1)$ & $(2)$ & (3) & (4) & $(5)$ & $(6)$ & $(7)$ & $(8)$ \\
\hline ratio_educ & $\begin{array}{l}0.173 * * \\
(0.0784)\end{array}$ & $\begin{array}{c}0.131^{*} \\
(0.0740)\end{array}$ & $\begin{array}{c}0.134^{*} \\
(0.0746)\end{array}$ & $\begin{array}{c}0.109 \\
(0.0743)\end{array}$ & & & & \\
\hline w_logwage & & $\begin{array}{c}0.0677 * * * \\
(0.0200)\end{array}$ & $\begin{array}{c}0.0659 * * * \\
(0.0203)\end{array}$ & $\begin{array}{c}0.0642 * * * \\
(0.0202)\end{array}$ & & & & \\
\hline h_logwage & & $\begin{array}{c}0.327 * * * \\
(0.0563)\end{array}$ & $\begin{array}{c}0.329 * * * \\
(0.0567)\end{array}$ & $\begin{array}{c}0.324 * * * \\
(0.0595)\end{array}$ & & & & \\
\hline ratio_wage & & & & & $\begin{array}{c}0.765 * * * \\
(0.293)\end{array}$ & $\begin{array}{l}0.560^{*} \\
(0.286)\end{array}$ & $\begin{array}{l}0.509^{*} \\
(0.290)\end{array}$ & $\begin{array}{l}0.484^{*} \\
(0.290)\end{array}$ \\
\hline w_educ & & & & & & $\begin{array}{c}0.0328 \\
(0.0203)\end{array}$ & $\begin{array}{c}0.0346^{*} \\
(0.0205)\end{array}$ & $\begin{array}{l}0.0368^{*} \\
(0.0209)\end{array}$ \\
\hline h_educ & & & & & & $\begin{array}{c}0.0677 * * * \\
(0.0196)\end{array}$ & $\begin{array}{c}0.0670 * * * \\
(0.0199)\end{array}$ & $\begin{array}{c}0.0613 * * * \\
(0.0202)\end{array}$ \\
\hline boy & & & $\begin{array}{r}-0.0655 \\
(0.130)\end{array}$ & $\begin{array}{c}-0.0747 \\
(0.129)\end{array}$ & & & $\begin{array}{r}-0.0115 \\
(0.133)\end{array}$ & $\begin{array}{r}-0.0111 \\
(0.132)\end{array}$ \\
\hline c_age & & & $\begin{array}{l}0.00837 \\
(0.0196)\end{array}$ & $\begin{array}{c}0.000985 \\
(0.0206)\end{array}$ & & & $\begin{array}{c}0.0219 \\
(0.0200)\end{array}$ & $\begin{array}{c}0.0105 \\
(0.0210)\end{array}$ \\
\hline w_age & & & & $\begin{array}{c}-0.00478 \\
(0.0174)\end{array}$ & & & & $\begin{array}{l}0.00858 \\
(0.0177)\end{array}$ \\
\hline h_age & & & & $\begin{array}{l}0.00862 \\
(0.0166)\end{array}$ & & & & $\begin{array}{c}-0.000878 \\
(0.0171)\end{array}$ \\
\hline tot_hh & & & & $\begin{array}{l}0.0344 * \\
(0.0206)\end{array}$ & & & & $\begin{array}{c}0.0472 * * \\
(0.0214)\end{array}$ \\
\hline nonfarm & & & & $\begin{array}{l}0.415^{*} \\
(0.219)\end{array}$ & & & & $\begin{array}{l}-0.245 \\
(0.221)\end{array}$ \\
\hline saving & & & & 0.242 & & & & $0.310 * *$ \\
\hline
\end{tabular}




\section{International Journal of Social Science and Economic Research}

ISSN: $2455-8834$

Volume:05, Issue:11 "November 2020"

\begin{tabular}{|c|c|c|c|c|c|c|c|c|}
\hline & & & & $(0.148)$ & & & & $(0.150)$ \\
\hline jewelry & & & & $\begin{array}{l}0.239^{*} \\
(0.135)\end{array}$ & & & & $\begin{array}{c}0.200 \\
(0.140)\end{array}$ \\
\hline urban & & & & $\begin{array}{c}-0.273^{* *} \\
(0.135)\end{array}$ & & & & $\begin{array}{l}-0.274 * \\
(0.139)\end{array}$ \\
\hline Constant & $\begin{array}{c}15.43 * * * \\
(0.110)\end{array}$ & $\begin{array}{c}10.07 * * * \\
(0.796)\end{array}$ & $\begin{array}{c}9.988 * * * \\
(0.819)\end{array}$ & $\begin{array}{c}9.712 * * * * \\
(0.889)\end{array}$ & $\begin{array}{c}14.62 * * * * \\
(0.247)\end{array}$ & $\begin{array}{c}13.88 * * * \\
(0.275)\end{array}$ & $\begin{array}{c}13.65 * * * \\
(0.356)\end{array}$ & $\begin{array}{c}13.19^{* * * *} \\
(0.502)\end{array}$ \\
\hline Observations & 388 & 388 & 388 & 388 & 388 & 388 & 388 & 388 \\
\hline
\end{tabular}

Standard errors in parentheses

$* * * \mathrm{p}<0.01, * * \mathrm{p}<0.05, * \mathrm{p}<0.1$

This is different from previous studies in which they found that in general children in cities with various access facilities would make it easier for them to meet their needs compared to children in rural areas. Another thing that makes this possible is that welfare measures in rural are simpler than in urban. People in rural areas prioritize primary needs including clothing needs while the needs in urban areas are more diverse such as the need for higher education, the need for entertainment so that the measurement of their well-being is more complex. Women's power measured by the wage ratio (columns 5-8) has the same consequences as power as measured by the education ratio. Women's power as measured by the wage ratio also has a positive influence on children's welfare. The higher the wage of women compared to their spouses, the higher the level of clothing expenditures for children so that children are more prosperous. Father's education, mother's education, the number of household members also have a positive role in children's welfare. Related to the household asset, when women's power is measured by the ratio of wages, the asset that contributes to the welfare of children is savings. So in this case, households with savings have more prosperous children compared to households without savings. In general, assets are a variable that maintains the level of household consumption including children's clothing expenditure.

Women's power as measured by the wage ratio proves that the wages received by women have a very significant influence on children's welfare. The higher the level of wages received by women, the greater the level of household expenditure to buy children's clothes. However, as shown in Table 1, the wage ratio still shows that women's wage rates are still below their partners. This indicates that the need for access to employment with a fair wage system. Thus, they are able to improve children's welfare. In general, women's power in the household will have an impact on improving children's welfare. The higher the education and the higher the wages, compared to their partners, women are able to meet the children's clothing needs as a picture of increasing child welfare. 


\section{International Journal of Social Science and Economic Research}

ISSN: $2455-8834$

Volume:05, Issue:11 "November 2020"

\section{Discussion}

Women's power in the household has an important role in children's welfare. The greater the power of women in the household, the higher the level of child welfare. Increased wages and women's education have a significant impact on meeting the needs of children's clothing. The important role of women's education to improve children's welfare has implications for the need for open access for women to receive higher education and an understanding of the importance of education for women's self-development. The same is true for wages. Women's wages have an important role in children's welfare, but statistically, the data shows that the wage ratio of women is still below one, which means that women's wages are still lower than men. This has implications for the need for a fair wage system so that women are more valued in the labor market.

\section{Acknowledgements}

This research was supported by Lembaga Penelitiandan Pengabdian Masyarakat Universitas Udayana. We thank our colleagues who provided insight and expertise that greatly assisted the research, although they may not agree with all of the interpretations/conclusions of this paper.

\section{References}

[1] Basu, K.,. "Gender and Say: A Model of Household Behaviour with Endogenously Determined Balance of Power," The Economic Journal, 116, 2006, pp.558-80.

[2] Doss, C., "Intrahousehold Bargaining and Resource Allocation in Developing Countries," The World Bank Research Observer, 28(1), 2013, pp.52-78.

[3] Dufflo, E., "Child Health and Household Resources in South Africa: Evidence from the Old Age Pension Program," The American Economic Review, 90(2), 2000, pp.393-98.

[4] Herskovits, M.J., “Organisasi Sosial: Struktur Masyarakat.” In T.O. Ihromi, ed. Pokokpokok Antropologi Budaya. - ed. Jakarta: Yayasan Pustaka Obor Indonesia. 2016,pp.105-41.

[5] Lundberg, S., Plaak, R. dan Wales, T., "Do Husbands and Wives Pool Their Resources? Evidence from the UK Child Benefit," Journal of Human Resources, 32(3), 1997, pp.46380 .

[6] Rahmawati, Ni Nyoman, "Perempuan Bali dalam Pergulatan Gender (kajian Budaya, Tradisi, dan Agama Hindu)," Jurnal Studi Kultural, 1(1) , 2016, pp. 58-64. 
[7] Reggio, I., "The Influence of the Mother's Power on Her Child's Labor in Mexico," Journal of Development Economics, 96, 2011, pp.95-105

[8] Webbink, E., Smits, J. \& de Jong, E.,. "Hidden Child Labor: Determinants of Houseworkk and Family Business Work of Children in 16 Developing Countries," World Development, 40(3), 2012, pp.631-42.

[9] Wooldridge, J.M.,. Introductory Economtrics: A Modern Aprroach. 4th ed. Mason: SouthWestern Cengage Learning. 2010. 